\title{
Conservation problems and research needs for Bristle-thighed Curlews Numenius tahitiensis on their wintering grounds
}

\author{
JEFFREY S. MARKS and ROLAND L. REDMOND
}

\section{Summary}

The Bristle-thighed Curlew Numenius tahitiensis is a rare shorebird that breeds in western Alaska and winters on oçeanic islands in the tropical and subtropical Pacific Ocean. Before human colonization, the islands on which curlews winter were devoid of terrestrial predators, allowing curlews to evolve a rapid moult during which about $50 \%$ of adults become flightless. Especially when flightless, these birds are vulnerable to harvest by humans and to predation by introduced mammals such as dogs and cats. On atolls where they are harvested by humans, curlews tend to occur only on uninhabited islets. Consequently, human encroachment in Oceania has probably reduced Bristle-thighed Curlew numbers and altered winter distribution of the species. Future studies should (1) identify concentrations of wintering curlews, focusing in the Tuamotu Archipelago; (2) determine whether migratory stopover sites exist in the central Pacific between Hawaii and the southern end of the wintering grounds; and (3) establish a monitoring programme to assess population trends in several parts of the winter range. A comprehensive plan is needed to provide for the existence of predator-free islands throughout key portions of the winter range.

\section{Introduction}

Shorebirds (suborders Charadrii and Scolopaci: Gochfeld et al. 1984) that breed at arctic and subarctic latitudes typically lay a four-egg clutch and seldom attempt to breed more than once each year (Myers et al. 1987). The trade-off for this low parental investment is high survivorship that allows multiple breeding attempts during an individual's lifetime (Evans 1981, Evans and Davidson 1990). Most shorebirds that breed at high latitudes are long-distance migrants that winter along continental coasts (Morrison 1984, Hayman et al. 1986). Spending most of their lives south of the breeding grounds, it is essential that shorebirds winter in areas where their chances of survival are high (Evans 1981). During migration, shorebirds tend to concentrate at traditional staging sites to replenish fat stores. Because these staging sites are restricted in size and surrounded by vast expanses of unsuitable habitat, they act as geographic bottlenecks for many shorebirds (Myers 1983, Myers et al. 1987). Thus, conservation of shorebird populations depends in large part on the existence of wintering areas and migratory stopover sites where the risk of mortality is low.

Bristle-thighed Curlews Numenius tahitiensis breed in subarctic tundra in two areas of western Alaska (perhaps representing separate populations) and winter on small islands in the tropical and subtropical Pacific Ocean (Stickney 1943, 
McCaffery and Gill 1992). Their breeding populations probably consist of no more than 7,00o individuals (Gill and Redmond 1992), and they were recently designated as a candidate for the U.S. Fish and Wildlife Service's list of threatened and endangered wildlife. Adults inhabit the wintering grounds from July or August to early May, and immature birds (less than three years old) remain on the wintering grounds throughout the year (Marks and Redmond 1994).

Bristle-thighed Curlews are the only migratory shorebirds that winter exclusively on oceanic islands. Their winter range was virtually free of terrestrial predators before the arrival of humans. Freedom from predation is probably responsible for their unusual moult, during which about $50 \%$ of the adults become flightless for approximately two weeks during autumn (Marks et al. 1990, Marks 1993). In addition, some individuals exhibit extreme longevity (surviving $>23$ years), and annual survivorship at the northern edge of the winter range is at least $85 \%$ (Marks 1992). Even though the breeding grounds are still relatively pristine, nest predation can be high during some years (McCaffery and Gill 1992). Given their high survivorship and potentially low reproductive success, Bristle-thighed Curlew populations will predictably be highly sensitive to factors that increase mortality away from the breeding grounds.

Among shorebirds, moult-induced flightlessness is unique to Bristle-thighed Curlews. Because flightless curlews are known from both the Northern and Southern Hemispheres (Marks et al. 1990), flightlessness is probably a widespread phenomenon in Bristle-thighed Curlews. On Laysan Island in the northwestern Hawaiian Islands, approximately $50 \%$ of the adult curlews become flightless for a brief period (perhaps two weeks) during the prebasic moult in autumn (Marks 1993). In marked contrast to volant individuals, flightless curlews are extremely secretive and seldom appear in the open during the daytime. Their typical reaction to humans is to seek cover in dense vegetation (pers. obs.). Flightless curlews run swiftly, but they can be readily captured by humans that pursue them diligently.

Information on the non-breeding ecology of Bristle-thighed Curlews comes from work conducted in the north-western Hawaiian Islands between 1988 and 1992 (Marks et al. 1990, Marks 1993, Marks and Redmond 1994) and from shortterm studies in the Marshall Islands (Johnson 1979) and the Tuamotu Archipelago (Gill and Redmond 1992). Little is known about curlews in other parts of Oceania. For example, staging areas presumed to exist between Hawaii and the southern end of the winter range have not been identified (Marks and Redmond 1994). Moreover, the effects of humans and introduced predators on curlews have not been examined critically, especially when adults are flightless. Given the devastating impact that humans have had on the avifauna of oceanic islands (e.g. Holyoak 1973, Moors 1985, Loope et al. 1988), Bristle-thighed Curlews are probably highly vulnerable to human-caused perturbations on their wintering grounds (Amadon 1953, Marks et al. 1990).

Gill and Redmond (1992) called for additional research on the distribution, numbers and ecology of Bristle-thighed Curlews in the Pacific. In this paper we expand upon their recommendations. Specifically, we (1) bring together current information on the distribution and numbers of the species in Oceania; (2) identify potential threats to wintering birds, focusing on the implications of moult-induced flightlessness; (3) examine the relationship between the presence 
of humans and curlews on atolls and small islands with different degrees of human disturbance; and (4) recommend directions for additional research and monitoring on the wintering grounds.

\section{Distribution and numbers on the wintering grounds}

Bristle-thighed Curlews winter (i.e. reside on the non-breeding grounds) from the north-western Hawaiian Islands south-west to the Marshall Islands, south to Fiji, and east to the Pitcairn Islands at the south-eastern end of the Tuamotu Archipelago (Figure 1). Extralimital winter records exist for the Caroline and Mariana islands in western Micronesia (Baker 1951), Norfolk Island and the Kermadec Islands north of New Zealand (Veitch 1974, Turbott 1990), and Easter Island, 2,315 km east of the Pitcairn Islands (Vilina et al. 1992).

Information on curlew numbers in various archipelagos from throughout the winter range is presented in Table 1 . The largest known concentrations of Bristle-thighed Curlews (700-80o birds) are in the north-western Hawaiian Islands, with most of the birds occurring on Laysan Island, Lisianski Island and Midway Atoll (pers. obs.). U.S. Fish and Wildlife Service personnel have counted more than 200 curlews on Palmyra Atoll in the northern Line Islands during each of three visits between 1987 and 1992 (unpubl. data, U.S. Fish and Wildlife Service, Honolulu, HI). Also in the northern Line Islands, Dick Watling (in litt.) estimated that 50-100 curlews were present on Washington Island (Tabuaeran) during February 1993. Kepler et al. (1994) counted 83 curlews at Caroline Atoll in the southern Line Islands in September 1988. Using line transects, they estimated that about 300 curlews wintered on the atoll; but because 154 curlews were calculated from a single flock of seven birds on one transect, their population estimate is probably inflated.

Gill and Redmond (1992) estimated that 250-300 curlews winter on Rangiroa Atoll in the northern Tuamotu Archipelago. Curlews winter throughout the rest of the Tuamotus (Bruner 1972, Lacan and Mougin 1974), but population estimates do not exist for atolls other than Rangiroa. Based largely on information from local residents, Lovegrove et al. (1989) concluded that the status of Bristlethighed Curlews in the northern Tuamotus has remained unchanged over the last 50 years. Nevertheless, residents of Rangiroa Atoll "stressed that curlews seem to be less common than 15-20 years ago" (Gill and Redmond 1992).

Recent studies in the Pitcairn Islands indicate that approximately 150 curlews winter on Oeno and Henderson islands (Brooke in press). Curlews are also widespread in the Marshall and Gilbert islands of Micronesia (Amerson 1969), and they occur regularly but in small numbers in Fiji and Tonga at the southwestern edge of the winter range (Watling 1982). Curlews also occur throughout the Cook Islands, with an estimated 200 inhabiting both Palmerston Atoll in 1960 (Burland 1964) and Takutea Island in 1973 (Holyoak 1976) and 1989-1990 (McCormack 1991). Curlews have been collected in the Phoenix, Society, and Marquesas islands (Stickney 1943), but we found no population estimates for these archipelagos.

\section{Threats from introduced predators}

A variety of mammals capable of preying upon birds has been introduced to Pacific islands, including three species of rat Rattus spp. (King 1985), a 


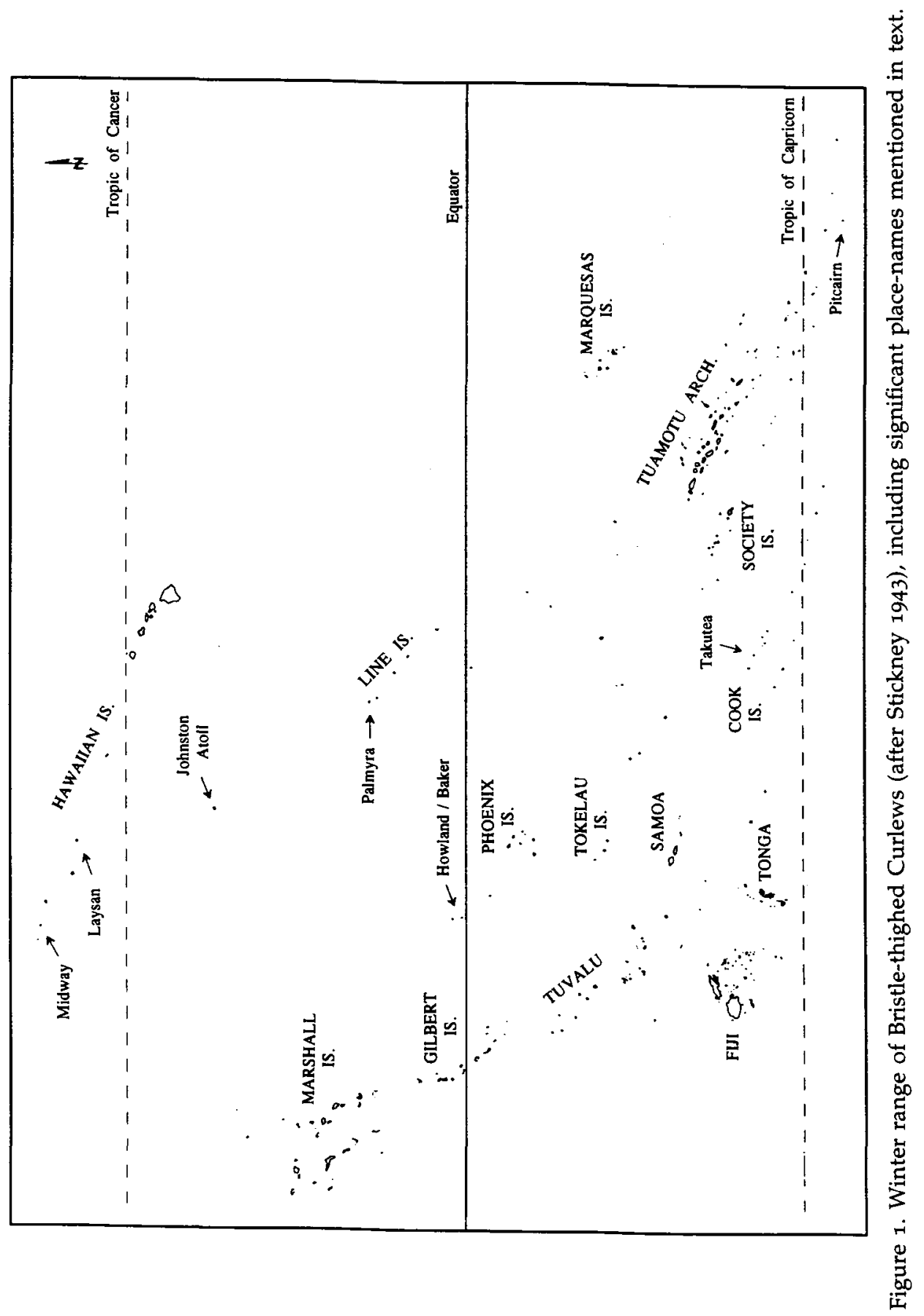


Table 1. Estimates of Bristle-thighed Curlew numbers for archipelagos in the main winter range, including islands with the highest known numbers of curlews within each archipelago.

\begin{tabular}{lcc}
\hline Archipelago & Population estimate & Source \\
\hline NW Hawaiian Islands & 800 & Marks unpubl. \\
Laysan Island & $300-350$ & Marks unpubl. \\
Lisianski Island & $300-400$ & Marks unpubl. \\
Midway Atoll & 100 & Marks unpubl. \\
Tuamotu Archipelago & Present & Bruner 1972 \\
Rangiroa Atoll & $250-350$ & Gill and Redmond 1992 \\
Pitcairn Islands & $>150$ & Brooke in press \\
Oeno Island & 100 & Brooke in press \\
Henderson Island & $40-50$ & Brooke in press \\
Marshall Islands & $>300$ & Amerson 1969 \\
Erikub Atoll & 100 & Amerson 1969 \\
Enewetak Atoll & 50 & Carpenter et al. 1968 \\
Gilbert Islands & $>100$ & Amerson 1969 \\
Makin Atoll & 27 & Amerson 1969 \\
Tokelau Islands & 40 & Thompson and Hackman 1968 \\
Cook Islands & Present & Holyoak 1980 \\
Palmerston Atoll & 200 & Burland 1964 \\
Takutea Island & 200 & Perry 1980 \\
Line Islands & Present & Holyoak 1976, McCormack 1991 \\
Palmyra Atoll & $>200$ & U.S. Fish and Wildlife Service \\
& & unpubl. data \\
Fanning Island & $50-100$ & Watling in litt. \\
Phoenix Islands & Present & Stickney 1943 \\
Society Islands & Present & Stickney 1943 \\
Marquesas Islands & Present & Stickney 1943 \\
\hline
\end{tabular}

anhabited by curlews but population estimates not available.

mongoose Herpestes auropunctatus, and feral and domestic populations of pigs Sus scrofa, dogs Canis familiaris, and cats Felis catus. Although rats are a serious threat to nesting seabirds (Kepler 1967, Atkinson 1985), they probably pose little danger to wintering Bristle-thighed Curlews, even when the birds are flightless. Curlews and other migratory shorebirds in Oceania are not as tame as nesting seabirds and are unlikely to be attacked by rats. Mongooses occur in Oceania only on Fiji and the main Hawaiian Islands (Nellis 1989), where curlews are not abundant. However, they could become a serious threat to curlews if introduced to additional portions of the winter range.

At Rangiroa Atoll, an islet inhabited by a single pig had almost no understorey vegetation (pers. obs.). Pigs undoubtedly have similar effects on the vegetation of small islands elsewhere in Oceania. In the north-western Hawaiian Islands, curlews feed primarily in vegetated terrestrial habitats and avoid intertidal zones for feeding (Marks and Hall 1992, Marks 1993). Islands with reduced vegetation would have lower food availability and less cover for moulting birds. Consequently, they would probably be avoided by curlews in areas where curlews rely heavily on vegetated habitats for foraging and escape cover.

Feral dogs and cats occur throughout much of Oceania (King 1973, Perry 1980), and they could pose a serious threat to curlews. Although volant curlews should be able to escape from dogs, flightless curlews would be especially vulnerable to 
Table 2. Counts of Bristle-thighed Curlews ${ }^{a}$ on Howland and Baker islands, northern Phoenix Islands. Cats were introduced to both islands in the late 1930 s and eliminated from Baker in 1964 and from Howland in 1986.

\begin{tabular}{lcc}
\hline Date & \multicolumn{2}{c}{ Number of curlews counted } \\
\cline { 2 - 3 } & Howland & Baker \\
\hline March 1963 & 2 & 0 \\
October 1963 & 2 & 5 \\
October 1964 & $13^{\mathrm{b}}$ & $\mathbf{1 0}$ \\
March 1976 & 0 & $\mathbf{1 4}$ \\
November 1977 & 0 & 25 \\
November 1978 & $\mathrm{o}$ & $\geqslant 5$ \\
April 1986 & 0 & 26 \\
September 1986 & 26 & 12 \\
September 1990 & 24 & 18 \\
\hline
\end{tabular}

a Unpublished data from Pacific Ocean Biological Survey Program (1963-1964) and U.S. Fish and Wildlife Service (1976-1990).

${ }^{b}$ Cats nearly eliminated by February 1964 but increased in number until completely eliminated in April 1986.

predation because dogs pursue their prey for long distances and can use olfaction to locate prey in dense vegetation. Cats can be devastating predators of island birds (Kirkpatrick and Rauzon 1986), and although normally they do not prey on species larger than themselves (Leyhausen 1979), they occasionally attack seabirds as large as cormorants Nannopterum harrisi and frigatebirds Fregata magnificens (Konecny 1987). Because they hunt by stealth and often forage nocturnally (when curlews would be less likely to detect them), we suspect that cats could prey upon curlews whether or not the curlews were flightless.

Data from two sites in the Phoenix Islands suggest that cats influence the distribution of Bristle-thighed Curlews. Cats were introduced to Howland and Baker islands in the late 1930s. Eradication efforts in 1963 and 1964 were successful at Baker but failed at nearby Howland. Subsequent visits to these islands indicated that curlews were largely absent from Howland until cats were completely eradicated in April 1986 (Table 2). Curlew numbers were relatively stable at Baker during the same period (Table 2). The absence of curlews at Howland while cats were present may have resulted from predation or from curlews leaving the island once they detected the cats. The rapid reappearance of curlews following cat eradication suggests that curlews responded directly to the presence of cats by moving elsewhere. We note that the effects of introduced predators could differ between atolls and islands. An atoll could continue to be inhabited by curlews as long as predators did not colonize all of the islets. Predators introduced to isolated islands, however, would be especially devastating to curlews if the birds could not move to another island.

\section{Threats from humans}

Disturbance by humans (including subsistence hunting) is apparently a great threat to Bristle-thighed Curlews on their wintering grounds. Perhaps because of their large size, curlews are highly prized for food by local peoples in Oceania. Reports of curlews being shot for food exist for the Line Islands (Kirby 1925) and the Cook Islands (Burland 1964, Holyoak 1980). Curlews are also trapped 
and eaten in the Tokelau Islands (Wodzicki and Laird 1970) and the Tuamotu Archipelago (Bruner 1972, Gill and Redmond 1992). Although the effects of harvest on curlew numbers are unknown, the potential for humans to influence numbers and distribution of curlews is great. For example, the fossil remains of Bristle-thighed Curlews are common in the main Hawaiian Islands (Olson and James 1982), yet today curlews are uncommon during migration and rarely overwinter (pers. obs.). The presence of humans, or of predators introduced by humans (e.g. dogs, cats and mongooses), could explain the absence of wintering Bristle-thighed Curlews in the main Hawaiian Islands. At present, the effects of humans on curlews can only be assessed indirectly. Curlews should actively avoid humans in areas where they are persecuted by them. Indeed, curlews tend to be especially wary throughout the central and southern portions of their winter range where they are harvested by humans (e.g. Bakus 1967, Pearson and Knudsen 1967, Child 1979, Holyoak 1980, Gill and Redmond 1992). This contrasts with the situation in the north-western Hawaiian Islands, where curlews have existed in the absence of human persecution for decades. On these islands, curlews are very tame and often approach humans during the daytime (pers. obs.). Nonetheless, even in the north-western Hawaiian Islands, curlews readily become wary if disturbed by people.

Between 1988 and 1991, we captured, measured and marked 349 curlews by spotlighting at night during five visits (ranging from $I$ to 4.5 months in duration) to Laysan Island. Laysan Island is part of the Hawaiian Islands National Wildlife Refuge and is uninhabited except when researchers are present. Even though our skill at catching curlews improved with each visit to the island, the birds became so wary that our success rate declined steadily from 0.36 to 0.13 adult captures per hour from our first to last visits $(r=-0.957, n=5, p=0.005)$. The decline in capture success resulted from a radical change in the behaviour of adult curlews. Early in our study, adults typically stood still when we shone our lights on them; by our fourth and fifth visits, however, they usually eluded capture by running off or taking flight, even on the darkest of nights.

Midway Atoll at the far end of the north-western chain has been a U.S. naval base since the $1940 \mathrm{~s}$. It became a wildlife refuge in 1988 under the joint management of the U.S. Navy and the U.S. Fish and Wildlife Service. Virtually all of the approximately 100 curlews that winter at Midway Atoll feed on Sand Island during the day but leave each evening to spend the night on Spit Island I $\mathrm{km}$ away (pers. obs.). About 250 people reside on Sand Island, whereas Spit Island is uninhabited. Introduced rats Rattus rattus, the only terrestrial mammals inhabiting the atoll, are present on both islands. Even though people no longer harass curlews at Midway, it is possible that the birds were persecuted from the 1940s through the 1970s when the atoll supported a thriving naval base occupied by up to 5,000 people (curlew numbers during this period are unknown). Thus, the curlews' current habit of spending the night on an uninhabited island may have resulted from events that occurred decades ago. Interestingly, curlews remained tame during the daytime at both Laysan and Midway, perhaps because they were pursued only at night at Laysan and were not threatened by humans during the day at Midway.

In areas where curlews are trapped (rather than shot) for food, flightlessness would render them especially vulnerable to harvest. Indeed, local residents at Rangiroa Atoll informed us that curlews were easily captured when they could 
not fly. The general absence of curlews on islands inhabited by humans (e.g. Amerson 1969, Schipper 1985, Gill and Redmond 1992) suggests that humans could alter the distribution of wintering curlews even where the birds are not harvested.

Atoll ecosystems are extremely fragile and thus easily modified by humans (Wodzicki 1981). The mere presence of humans, such as might occur with tourism development or the establishment of military installations, could have adverse effects on curlew numbers. We note, however, that some workers are not convinced that curlews avoid humans. For example, J.-C. Thibault (in litt.) feels that curlew numbers are not higher on uninhabited atolls than on inhabited atolls in the Tuamotu Archipelago. Clearly, more information is needed on the distribution of curlews and humans in Oceania.

\section{Conservation and research needs}

The conservation of Bristle-thighed Curlews will depend on the existence of uninhabited, predator-free islands in key portions of the winter range. Unfortunately, information on curlew distribution and numbers is either outdated or non-existent for most of Oceania, and it would be extremely difficult and expensive to obtain. Nonetheless, we believe that sufficient data exist to allow conservation and research efforts to focus on the island groups most likely to be in need of attention. The major concerns that must be considered in any comprehensive plan to conserve Bristle-thighed Curlews are: (1) identification of high concentrations of wintering curlews, (2) identification of migratory stopover sites, (3) monitoring of population trends, and (4) protection and management of key islands and atolls throughout the winter range. Below, we suggest locations in which each of these concerns might best be addressed.

\section{Concentrations of curlews}

The highest recent counts of Bristle-thighed Curlews are from Laysan and Lisianski islands in the north-western Hawaiian Islands, Palmyra Atoll in the Line Islands, and Takutea Island in the Cook Islands (Table 1). The vast Tuamotu Archipelago is the most likely place to expect additional concentrations of wintering curlews because it has large numbers of uninhabited atolls (Table 3). Consequently, expeditions to the Tuamotus during the "wintering" period (i.e. September to April) should include efforts to monitor curlews with the aim of identifying atolls with relatively high numbers of birds. Efforts to determine curlew numbers in the Tuamotus have been attempted by Lovegrove et al. (1989), but, as they noted, it is "extremely difficult to arrive at any meaningful population figures". This difficulty underscores the need to determine numbers using mark-resighting analyses and systematic surveys (see below).

\section{Migratory stopover sites}

Data from Laysan Island indicate that curlews wintering in the South Pacific overfly the north-western Hawaiian Islands during both northward and southward migration (Marks and Redmond 1994). Assuming that curlews cannot fly 
Table 3. Major archipelagos used by wintering Bristle-thighed Curlews classified by number of atolls and islands that are inhabited by humans.

\begin{tabular}{|c|c|c|c|c|}
\hline & \multicolumn{2}{|c|}{ Number of atolls } & \multicolumn{2}{|c|}{ Number of islands } \\
\hline & Humans & No humans & Humans & No humans \\
\hline NW Hawaiian Is. ${ }^{a}$ & 2 & 2 & o & 4 \\
\hline Marshall Is. ${ }^{\text {b }}$ & 20 & 8 & 4 & 1 \\
\hline Gilbert Is. ${ }^{\mathrm{b}}$ & 10 & 0 & 6 & o \\
\hline Phoenix Is. ${ }^{c}$ & $\mathbf{1}$ & 2 & 0 & 7 \\
\hline Line Is. ${ }^{d}$ & 2 & 2 & 1 & 5 \\
\hline Marquesas Is. ${ }^{c}$ & 0 & o & 6 & 4 \\
\hline Tuamotu Arch. ${ }^{c}$ & 39 & 37 & $\mathbf{1}$ & 0 \\
\hline Society Is. ${ }^{\mathrm{c}}$ & 4 & 3 & 6 & 1 \\
\hline Cook Is. ${ }^{c}$ & 6 & $\mathbf{I}$ & 7 & $\mathbf{1}$ \\
\hline Pitcairn Is. ${ }^{c}$ & o & 2 & $\mathbf{1}$ & 1 \\
\hline Tokelau Is. ${ }^{c}$ & 3 & o & o & o \\
\hline Tuvalu Is. ${ }^{c}$ & 5 & 1 & 3 & o \\
\hline
\end{tabular}

pers. obs.

b Amerson (1969).

'Douglas (1989).

d Perry (1980).

non-stop between Alaska and the southern portion of their winter range (a distance of more than $8,500 \mathrm{~km}$ ), migratory stopover sites must exist somewhere between Hawaii and the South Pacific. These sites could be essential for the successful migration of curlews that winter throughout the South Pacific.

Migratory flight range estimates suggest that curlews departing from Alaska could fly non-stop to the northern Line Islands, Phoenix Islands, Marshall Islands and Gilbert Islands (Marks and Redmond 1994). Based on the presence of large numbers of curlews during southward migration, a probable stopover site is Palmyra Atoll in the northern Line Islands. Palmyra is uninhabited but is slated for major development as a tourist facility. Consequently, the need to determine its significance to curlews, and to take protective measures if necessary, is especially urgent. The Phoenix Islands are largely uninhabited (Table 3) and thus might also contain important stopover sites. In contrast, most of the islands in the Marshall and Gilbert archipelagos are inhabited (Table 3), making them less likely to be used by large numbers of curlews. Moreover, the island groups south of these islands (i.e. Tuvalu, Fiji, Tonga and Samoa) are not known to support large numbers of curlews. Another reason that the Line and Phoenix islands are likely to contain staging sites is that they are along the most direct route between Alaska and the islands thought to contain large numbers of wintering curlews (i.e. the Cook Islands and Tuamotu Archipelago).

\section{Assessing population trends}

Monitoring of population trends should be based on information from several widely spaced areas. Sites that can be visited relatively easily and that contain large numbers of curlews would make the best locations. Likely sites would include the north-western Hawaiian Islands (e.g. Midway Atoll or Laysan Island), the Cook Islands (e.g. Takutea Island) and the Line Islands (e.g. 
Christmas Island or Palmyra Atoll). At each location, curlew numbers should be assessed using mark-resighting analyses based on systematic surveys of colour-ringed individuals. Special efforts should be made to assess numbers during the moulting period when curlews are sedentary (i.e. October through November) and during migration periods at suspected staging sites.

In addition to monitoring numbers, more data are needed on basic life-history parameters such as moulting patterns, feeding habits and habitat affinities in the Southern Hemisphere. Although this information is known for curlews in the north-western Hawaiian Islands, it cannot necessarily be extended to curlews at the southern end of their winter range. For example, Bristle-thighed Curlews forage primarily in vegetated habitats in the north-western Hawaiian Islands (pers. obs.). In the Southern Hemisphere, however, they forage extensively in both vegetated and unvegetated habitats (Gill and Redmond 1992, Kepler et al. 1994, Brooke in press). Consequently, the effects of habitat alteration on curlews might differ between the northern and southern portions of their winter range.

\section{Protection and management}

The protection of atolls and islands that are of high value to curlews will probably be the most difficult task to accomplish. Fortunately, the north-western Hawaiian Islands are already protected as a National Wildlife Refuge and are free of predators capable of capturing curlews. Wildlife sanctuaries have also been established on several of the Line Islands (Perry 1980), Phoenix Islands (IUCN 1991) and Marquesas Islands (IUCN 1991), and at Takutea in the Cook Islands (McCormack 1991) and Atoll de Taiaro in the Tuamotu Archipelago (IUCN 1991). Conservation efforts in the rest of Oceania will probably need to involve the removal of predators on some islands and the establishment and enforcement of regulations that prohibit the harvest of curlews. As noted previously (Gill and Redmond 1992), an effective conservation and monitoring effort must involve the cooperation of the governments of the United States, France, New Zealand and Kiribati.

\section{Acknowledgements}

We are grateful to Joe Ball, Bob Gill, Luciana Honigman and Ken McDermond for aiding our research effort in many ways. We also thank A. J. Stattersfield and Bob Gill for improving an earlier version of the manuscript; J.-C. Thibault and Dick Watling for information from the Southern Hemisphere; Milo Burcham, Dave Evans, Paul Hendricks and Shawne Leasure for assisting in the field; Claudine Leger for translating two papers; and Jim Schumacher for drafting the figure. Our work was supported by the U.S. Fish and Wildlife Service (Alaska Fish and Wildlife Research Center, Hawaiian Islands National Wildlife Refuge, Montana Cooperative Wildlife Research Unit), National Geographic Society, World Wildlife Fund, University of Montana Bertha Morton Fellowships, Hawaii Audubon Society, Sigma Xi, a Paul A. Stewart award, and a Curby-Pavelsky-Harris award. The U.S. National Marine Fisheries Service, the 
U.S. Coast Guard, and the NOAA research vessel Townsend Cromwell provided logistic support.

\section{References}

Amadon, D. (1953) Migratory birds of relict distribution: some inferences. Auk 70: 461469.

Amerson, A. B. (1969) Ornithology of the Marshall and Gilbert islands. Atoll Res. Bull. 127.

Atkinson, I. A. E. (1985) The spread of commensal species of Rattus to oceanic islands and their effects on island avifaunas. Pp.35-81 in P. J. Moors, ed. Conservation of island birds. Cambridge, U.K.: International Council for Bird Preservation (Techn. Publ. 3).

Baker, R. H. (1951) The avifauna of Micronesia, its origin, evolution, and distribution. Univ. Kansas Publ. Mus. Nat. Hist. 3: 1-359.

Bakus, G. J. (1967) Changes in the avifauna of Fanning Island, central Pacific, between 1924 and 1963. Condor 69: 207-209.

Brooke, M. de L. (in press) The modern avifauna of the Pitcairn Islands, South Pacific. Biol. J. Linn. Soc.

Bruner, P. L. (1972) Field guide to the birds of French Polynesia. Honolulu: Bernice P. Bishop Museum.

Burland, J. C. (1964) Some notes on the bird life of Palmerston Atoll. Notornis 11: 145154.

Carpenter, M. L., Jackson, W. B. and Fall, M. W. (1968) Bird populations at Eniwetok Atoll. Micronesica 4: 295-307.

Child, P. (1979) Some bird observations from Western Samoa. Notornis 26: 171-179.

Douglas, N. (1989) Pacific islands yearbook. Suva: Fiji Times.

Evans, P. R. (1981) Migration and dispersal of shorebirds as a survival strategy. Pp.275290 in N. V. Jones and W. J. Wolff, eds. Feeding and survival strategies of estuarine organisms. New York: Plenum Press.

Evans, P. R. and Davidson, N. C. (1990) Migration strategies and tactics of waders breeding in arctic and north temperate latitudes. Pp.387-398 in E. Gwinner, ed. Bird migration: physiology and ecophysiology. Berlin: Springer-Verlag.

Gill, R. E. and Redmond, R. L. (1992) Distribution, numbers, and habitat of Bristlethighed Curlews Numenius tahitiensis on Rangiroa Atoll. Notornis 39: 17-26.

Gochfeld, M., Burger, J. and Jehl, J. R., Jr. (1984) The classification of the shorebirds of the world. Pp.1-15 in J. Burger and B. L. Olla, eds. Shorebirds: breeding behavior and populations. New York: Plenum Press.

Hayman, P., Marchant, J. and Prater, T. (1986) Shorebirds: an identification guide. Boston: Houghton Mifflin.

Holyoak, D. T. (1973) Endangered land-birds in French Polynesia. Biol. Conserv. 5: 231232.

Holyoak, D. T. (1976) Records of waders in the Cook Islands. Notornis 23: 1-3.

Holyoak, D. T. (1980) Guide to Cook Island birds. Published by author.

IUCN (1991) IUCN directory of protected areas in Oceania. Cambridge, U.K.: International Union for Conservation of Nature.

Johnson, O. W. (1979) Biology of shorebirds summering on Enewetak Atoll. Stud. Avian Biol. 2: 193-205.

Kepler, C. B. (1967) Polynesian rat predation on nesting Laysan Albatrosses and other Pacific seabirds. Auk 84: 426-430.

Kepler, C. B., Kepler, A. K. and Ellis, D. H. (1994) The natural history of Caroline Atoll, southern Line Islands. Part II. Seabirds, other terrestrial animals, and conservation. Atoll Res. Bull. 398. 
King, W. B. (1973) Conservation status of birds of central Pacific islands. Wilson Bull. 85: 89-103.

King, W. B. (1985) Island birds: will the future repeat the past? Pp.3-15 in P. J. Moors, ed. Conservation of island birds. Cambridge, U.K.: International Council for Bird Preservation (Techn. Publ. 3).

Kirby, H. (1925) The birds of Fanning Island, central Pacific Ocean. Condor 27: 185-196.

Kirkpatrick, R. D. and Rauzon, M. J. (1986) Foods of feral cats Felis catus on Jarvis and Howland islands, central Pacific Ocean. Biotropica 18: $7^{2-75}$.

Konecny, M. J. (1987) Food habits of feral house cats in the Galápagos Islands. Oikos 50: 24-32.

Lacan, F. and Mougin, J.-L. (1974) Les oiseaux des lles Gambier et de quelques atolls orientaux de L'Archipel des Tuamotu (Océan Pacifique). Oiseau et R.F.O. 44: 192-284.

Leyhausen, P. (1979) Cat behavior: the predatory and social behavior of domestic and wild cats. New York: Garland Press.

Loope, L. L., Hamann, O. and Stone, C. P. (1988) Comparative conservation biology of oceanic archipelagoes. BioScience 38: 272-282.

Lovegrove, R., Mann, I., Morgan, G. and Williams, I. (1989) Tuamotu Islands expedition report. Unpublished.

Marks, J. S. (1992) Longevity record for the Bristle-thighed Curlew: an extension. J. Field Orn. 63: 309-310.

Marks, J. S. (1993) Molt of Bristle-thighed Curlews in the Northwestern Hawaiian Islands. Auk 110: 573-587.

Marks, J. S. and Hall, C. S. (1992) Tool use by Bristle-thighed Curlews feeding on albatross eggs. Condor 94: 1032-1034.

Marks, J. S. and Redmond, R. L. (1994) Migration of Bristle-thighed Curlews on Laysan Island: timing, behavior and estimated flight range. Condor 96: 316-330.

Marks, J. S., Redmond, R. L., Hendricks, P., Clapp, R. B. and Gill, R. E. (1990) Notes on longevity and flightlessness in Bristle-thighed Curlews. Auk 107: 779-781.

McCaffery, B. J. and Gill, R. E. (1992) Antipredator strategies in breeding Bristle-thighed Curlews. Amer. Birds 46: 378-383.

McCormack, G. (1991) Takutea: a wildlife report from 1986 to 1990. Rarotonga, Cook Islands: Research Division, Prime Minister's Department, unpublished.

Moors, P. J., ed. (1985) Conservation of island birds. Cambridge, U.K.: International Council for Bird Preservation (Techn. Publ. 3).

Morrison, R. I. G. (1984) Migration systems of some New World shorebirds. Pp.125-202 in J. Burger and B. L. Olla, eds. Shorebirds: migration and foraging behavior. New York: Plenum Press.

Myers, J. P. (1983) Conservation of migrating shorebirds: staging areas, geographic bottlenecks, and regional movements. Amer. Birds 37: 23-25.

Myers, J. P., Morrison, R. I. G., Antas, P. Z., Harrington, B. A., Lovejoy, T. E., Sallaberry, M., Senner, S. E. and Tarak, A. (1987) Conservation strategy for migratory species. Amer. Sci. 75: 19-26.

Nellis, D. W. (1989) Herpestes auropunctatus. Lawrence, Kansas: American Society of Mammalogists (Mammalian Species 342: 1-6).

Olson, S. L. and James, H. F. (1982) Prodromus of the fossil avifauna of the Hawaiian Islands. Smithson. Contrib. Zool. 365: 1-59.

Pearson, D. L. and Knudsen, J. W. (1967) Avifaunal records from Eniwetok Atoll, Marshall Islands. Condor 69: 201-203.

Perry, R. (1980) Wildlife conservation in the Line Islands, Republic of Kiribati (formerly Gilbert Islands). Environ. Conserv. 7: 311-318.

Schipper, W. L. (1985) Observations of birds on Kwajalein Atoll 1978-1983. Elepaio 6: 27-32. 
Stickney, E. H. (1943) Birds collected during the Whitney South Sea Expedition: northern shore birds in the Pacific. Amer. Mus. Novit. 1248.

Thompson, M. C. and Hackman, C. D. (1968) Birds of the Tokelau Islands. Notornis 15: 109-117.

Turbott, E. G. (1990) Checklist of the birds of New Zealand and the Ross Dependency, Antarctica. Third edition. Wellington: Ornithological Society of New Zealand.

Veitch, C. R. (1974) Bristle-thighed Curlew records from the Kermadec Islands. Notornis 21: 83-84.

Vilina, Y. A., Larrea, A. and Gibbons, J. E. (1992) First record of the Bristle-thighed Curlew Numenius tahitiensis in Easter Island, Chile. Wader Study Group Bull. 66: 43-44.

Watling, D. (1982) Birds of Fiji, Tonga and Samoa. Wellington: Millwood Press.

Wodzicki, K. (1981) Some nature conservation problems in the South Pacific. Biol. Conserv. 21: 5-18.

Wodzicki, K. and Laird, M. (1970) Birds and bird lore in the Tokelau Islands. Notornis 17: $247-276$.

JEFFREY S. MARKS

Division of Biological Sciences, University of Montana, Missoula, MT 59812, U.S.A. Present address: U.S. Fish and Wildlife Service, P.O. Box 50167, Honolulu, HI 96850, U.S.A.

ROLAND L. REDMOND

Cooperative Wildlife Research Unit, University of Montana, Missoula, MT 59812, U.S.A. 